\title{
Interaction between lifestyle factors and the XRCC1, XPD, and XRCC3 genetic variations modulates the risk for sporadic colorectal cancer
}

\author{
Interacțiunea factorilor de mediu cu variațiile genetice \\ localizate în genele XRCC1, XPD, and XRCC3 \\ modulează riscul pentru cancerul colorectal sporadic
}

\author{
Lucia Maria Procopciuc $^{*}$, Gelu Osian ${ }^{2}$ \\ 1. Department of Medical Biochemistry, "Iuliu Hatieganu” University of Medicine and Pharmacy, \\ Cluj-Napoca, Romania \\ 2. 3rd Surgical Clinic, Cluj-Napoca, Romania
}

\begin{abstract}
Background: Genetic variations, such as those affecting DNA repair genes, could represent susceptibility factors for sporadic colorectal cancer (CRC) as a result of their interaction with environmental factors. Materials and methods: 80 female and 70 males patients diagnosed with sporadic CRC in the Surgical Clinic III Cluj were genotyped for Arg399Gln-XRCC1, Lys751Gln-XPD and Met241Thr-XRCC3 using PCR-RFLP methods. We also genotyped 100 females and 62 males, who formed the control group. Genotyping results were related to environmental risk factors, smoking habit and diet. Results: Male patients carriers of the Arg399Gln, Lys751Gln, Met241Thr had a 4.09 (95\%CI[0.96-19.98], $p=0.05$ )-fold, 5.95(95\%CI[1.08-43.22], $p=0.03)$-fold and 3.73(95\%CI[0.8618.53],p=0.05)- fold significantly increased risk to develop sporadic CRC if they smoked. A significantly increased risk for CRC was observed in females and males with high daily fried red meat intake, carriers of the Arg399Gln (OR 2.77 95\%CI [1.34-6.82],p=0.015 and OR 8.64 95\%CI[2.67-29.14],p<0.001), Lys751Gln (OR $4.1295 \%$ CI[1.37-12.74], $p=0.007$ and OR 5.06 95\%CI[1.4-19.02],p=0.006), Met241Thr (OR5.92 95\%CI[2.2116.23],p<0.001 and OR $5.6495 \%$ CI[1.52-21.7],p=0.022). Female patients with high fried red meat intake had a significantly higher risk to develop early-onset sporadic CRC if they were carriers of the Arg399Gln-XRCC1 (OR 5.14 95\%CI[0.99-28.3],p=0.047), Thr241Met-XRCC3 (OR 6.67 95\%CI[1.05-46.67],p=0.025) and Lys751Gln-XPD (OR 4.7 95\%CI[0.99-23.32],p=0.034). Conclusions: In Romanians, the association between the mutated genotypes and environmental risk factors modulates the risk for sporadic CRC. Smoking in association with the Arg399Gln-XRCC1 genetic variation influences the early onset of sporadic colorectal cancer in females. Diet rich in fried red meat intake associated with Arg399Gln-XRCC1, Lys751Gln-XPD and Thr241Met-XRCC3 genetic variations significantly influences the early onset of sporadic colorectal cancer in females.
\end{abstract}

Keywords: Arg399Gln-XRCC1, Lys751Gln-XPD, Thr241Met-XRCC3, PCR-RFLP, environmental exposure, Romania

"Corresponding author: Lucia Maria Procopciuc, Department of Medical Biochemistry, "Iuliu Hatieganu" University of Medicine and Pharmacy, Cluj-Napoca, Romania, email address: luciamariaprocopciuc@yahoo.com 


\section{Rezumat}

Introducere: Variațiile genetice, cum ar fi cele care influențează sistemele de reparare a defectelor de replicare a ADN, pot reprezenta factori de susceptibilitate in cancerul colorectal sporadic (CCR) ca urmare a interacțiunii cu factori de mediu. Material și metodă: 80 de femei și 70 de bărbați, pacienți diagnosticați cu CCR sporadic în Clinica Chirurgie III Cluj au fost genotipați pentru Arg399Gln-XRCC1, Lys751Gln-XPD și Met241Thr-XRCC3 utilizând metodele PCR-RFLP. Am determinat de asemenea, genotipurile pentru 100 femei și 62 bărbați, care au format grupul de control. Rezultatele au fost analizate din punct de vedere al relației cu factorii de risc de mediu, fumatul și dieta. Rezultate: Bărbații fumători purtători ai variațiilor genetice Arg399Gln, Lys751Gln, Met241Thr au avut un risc semnificativ crescut de 4.09 (95\%IC[0.96-19.98],p=0.05), 5.95(95\%IC[1.08-43.22],p=0.03) și respectiv 3.73(95\%IC [0.86-18.53],p=0.05) de a dezvolta cancer colorectal sporadic. Un risc semnificativ crescut de a dezvolta cancer colorectal sporadic a fost observat în cazul femeilor și bărbaților cu o dietă bogată in carne roșie prăjită purtători ai variațiilor genetice Arg399Gln (OR 2.77 95\%IC [1.34-6.82],p=0.015 și OR 8.64 95\%IC[2.67-29.14],p<0.001), Lys751Gln (OR 4.12 95\%IC[1.37-12.74],p=0.007 și OR 5.06 95\%IC[1.419.02],p=0.006), Met241Thr (OR5.92 95\%IC[2.21-16.23],p<0.001 și OR 5.64 95\%IC[1.52-21.7],p=0.022). Femeile a căror dietă a inclus cantități mari de carne roșie prăjită au avut un risc semnificativ crescut de a dezvolta timpuriu cancer colorectal sporadic dacă au fost purtătoare a variațiilor genetice Arg399Gln-XRCC1 (OR 5.14 95\%IC[0.99-28.3],p=0.047), Thr241Met-XRCC3 (OR 6.67 95\%IC[1.05-46.67],p=0.025) şi Lys751Gln-XPD (OR 4.7 95\%IC[0.99-23.32],p=0.034). Concluzii: În cazul populației de origine română, asocierea genotipurilor mutante cu factori de mediu modulează riscul pentru CCR sporadic. La femei, fumatul în asociere cu variația genetică Arg399Gln-XRCC1 influențează debutul timpuriu al cancerului colorectal sporadic. Tot în cazul femeilor, dieta bogată în carne roșie prăjită în asociere cu variațiile genetice Arg399Gln-XRCC1, Lys751Gln-XPD și Thr241Met$X R C C 3$ influențează semnificativ riscul de apariție al cancerului colorectal sporadic.

Cuvinte cheie: Arg399Gln-XRCC1, Lys751Gln-XPD, Thr241Met-XRCC3, PCR-RFLP, expunere la factori de mediu, România

Received: $18^{\text {th }}$ April 2013; Accepted: $31^{\text {st }}$ October 2013; Published: $10^{\text {th }}$ March 2014.

\section{Introduction}

Carcinogenesis involves the interaction of genetic risk factors and compounds of tobacco smoke with carcinogenic properties or from the pyrolysis of red meat. It is known that smoking represents a causal risk factor for multiple smaller or larger colorectal adenoma formation. At the same time, the risk of recurrence is increased in smoking patients. Because adenoma formation is the precursor of carcinomas, we could say that smoking is a risk factor for carcinogenesis (1-3). Carcinogenic compounds (polycyclic aromatic hydrocarbons, nitrosamines, and arylamines) determine DNA damage such as single- and double-strand breaks and base adduct formation (thymine glycol, 5-hydroxymethyluracil, and 8-hydroxy-2-deoxyguanosine). Also, in colon cancer cells, smoking induces the overexpression of 5-lipoxygenase or vascular endothelium growth factor, two proteins associated with colon tumor progression and invasion $(4,5)$. On the other hand, a diet rich in fried red meat has also been reported to be associated with colorectal adenomas (6-8).

DNA damage caused by carcinogenic compounds from smoking and fried red meat could be repaired through two pathways, the base excision repair pathway (BER) and the nucleotide excision repair pathway (NER). BER pathways, through XRCC1 (X-ray cross-complementation group 1), could repair single-strand breaks, while NER pathways, through XPD (Xeroderma 
pigmentosum group D), could repair bulky adducts (9-12). The X-ray cross-complementation group 3 (XRCC3) is a product of a member of the RAD51-related gene, involved in the recombination repair of double strand breaks of DNA (RR) process $(1,13)$.

There are different genetic variations located in the genes encoding for proteins involved in the DNA repair process, which determine decreased enzyme activity and affect the DNA repair capacity. Three of these genetic variations are Arg399Gln (exon 10 - XRCC1 gene), Lys751Gln (exon 23 - XPD gene), and Thr241Met (exon 7 - XRCC3 gene) (1).

Aim: to investigate three genetic variants located in genes that participate in BER (XRCC1) and NER (XPD) pathways, and XRCC3 that participates in the homologous recombination repair in association with lifestyle (smoking behavior and diet) as a risk factor for sporadic colorectal cancer in both women and men of Romanian origin; we also investigated the role of the interaction of genetic and environmental risk factors in early-onset cancer.

\section{Materials and methods}

\section{Patient groups}

We included in this study 150 patients with sporadic CRC. Diagnosis was made by colonoscopy and was confirmed after histopathological examination at the Surgical Clinic III Cluj. Eligible patients had an average age of $63.83 \pm$ 1.18 years, $80(53.33 \%)$ were females and 70 $(46.67 \%)$ were males. Patients included in these groups gave their informed consent and were interviewed. The consent form contained information on the subject such as name, age, gender and address, family history of colorectal cancer or other forms of cancer, smoking habit, diet. They had no other colorectal cancer (familial adenomatous polyposis, hereditary non-polyposis colorectal cancer) or inflammatory bowel dis- ease. The control group consisted of 162 individuals with an average age of $64.09 \pm 0.83$ years, $100(61.73 \%)$ females and 62 (38.27\%) males, without a positive personal or family history of colorectal cancer. They were referred for colonoscopy because they had medical symptoms such as rectorrhagia, transit disorders, tenesmae, anemia, subocclusion and occlusion. Genotyping results were related to environmental risk factors, smoking behavior (yes or no) and diet. We considered fried red meat intake to be high if patients ate fried red meat for more than five days a week. The study was approved by the local Ethics Committee of our university. Physical parameters of the patients and controls included in the study are presented in Table I.

\section{Methods}

Blood was collected from each patient and control in ethylene-diamine-tetra-acetate (EDTA) vacutainers and genomic DNA was extracted. Amplification of the required product was carried out in $25 \mu$ l volume of the reaction mixture. We amplified the DNA fragments of interest in $25 \mu \mathrm{l}$ using $5 \mu \mathrm{l}$ genomic DNA, $0.2 \mu \mathrm{M}$ of each of the primers, $200 \mathrm{mM}$ dNTPs, $0.625 \mathrm{U}$ Taq DNA polymerase. The sequences of the primers were those used by Matullo et al (2001), Lunn et al (2000 and 1999) (11, 14, 15). PCR products were digested for 3 hours with $5 \mu \mathrm{l}$ specific enzyme (MspI-XRCC1, NcoI-XRCC3 and PstI-XPD) in a total volume of $10 \mu \mathrm{l}$. For Arg399Gln-XRCC1, digestion yielded two 374 bp and 221 bp fragments (Arg399 allele) and an undigested $615 \mathrm{bp}$ fragment (Gln399 allele). For Lys751Gln-XPD, digestion yielded two 646 bp and 88 bp fragments (Gln751 allele) and an undigested $734 \mathrm{bp}$ fragment (Lys751 allele). For Thr241Met-XRCC3, digestion yielded two 97 bp and 39 bp fragments (Met241 allele) and an undigested $136 \mathrm{bp}$ fragment (Thr241 allele). The amplified and digested fragments were identified 


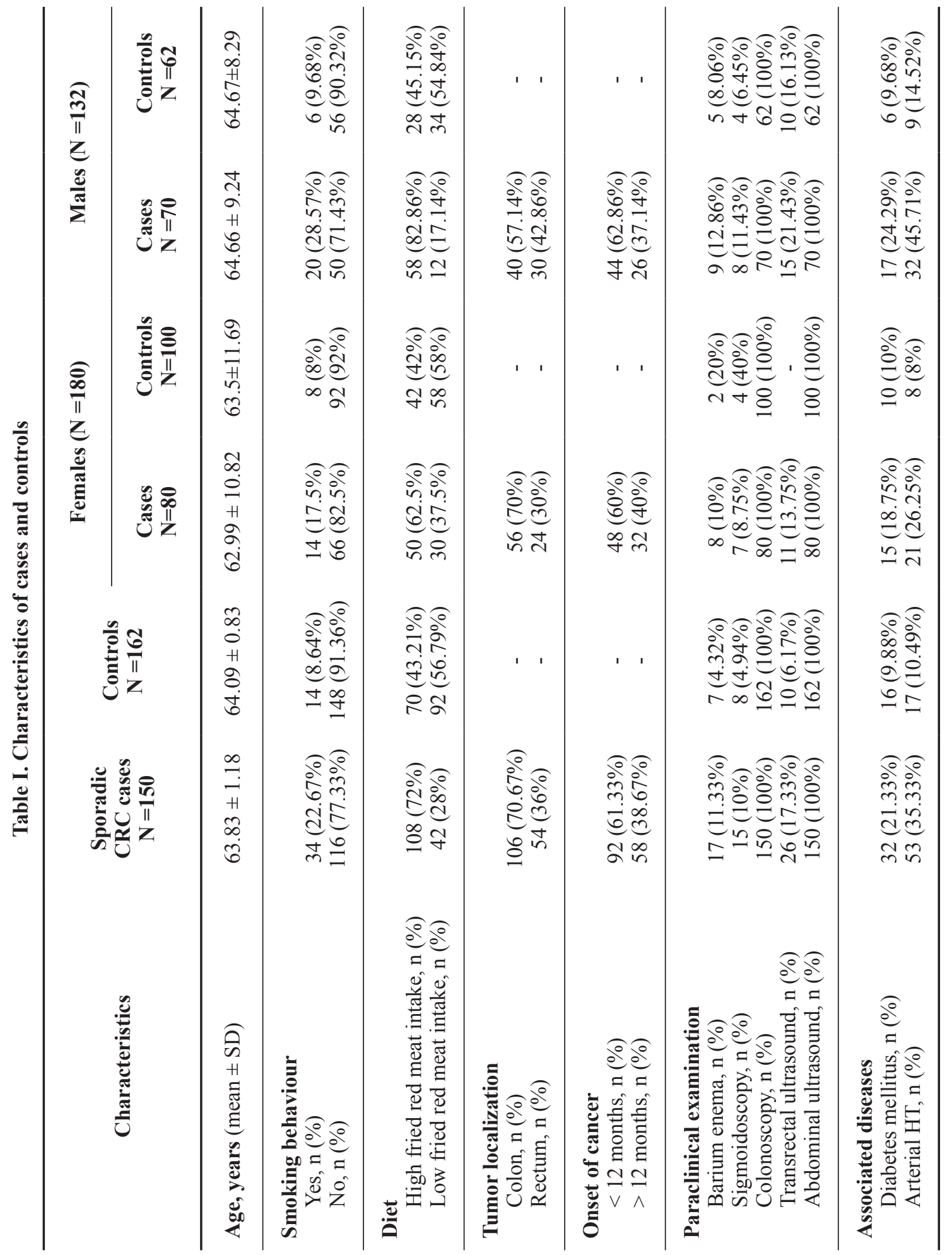


by agarose gel electrophoresis and the gels were stained with ethidium bromide solution. All the reagents were from Fermentas except the primers which were from Eurogentec.

\section{Statistical analysis}

We calculated genotype and allele frequencies for both patients and controls and we estimated relative risk and odds ratio (OR) by $\chi 2$ analysis using SPSS ${ }^{\circledR}$ Software version 12 for Windows (SPSS Inc., Chicago Illinois, USA 1989-2003). 95\%CI were calculated. $p$ values less than 0.05 were considered to have statistical significance. We also investigated the interaction of smoking and diet with genetic risk factors and the influence of risk factors on the onset of cancer using the same test.

\section{Results}

Atotal of 150 patients with sporadic CRC were genotyped in this study for Arg399Gln-XRCC1, Lys751Gln-XPD and Thr241Met-XRCC3 genetic variations. 162 subjects without confirmed malignancy signs formed the control group. There were no statistical differences in the age of subjects between the two groups, but there were differences in lifestyle, smoking behavior and daily meat intake, with a higher frequency in the patients group as compared to controls. Also, there was a higher frequency of smokers among both female and male patients compared to female and male controls. Both female and male patients had a diet rich in fried red meat intake compared to controls (Table I). Higher frequency of the Arg399Gln-XRCC1 (72\% vs. 45.68\%), Lys751Gln-XPD (52.67\% vs. $41.98 \%$ ) and Thr241Met-XRCC3 (65.33\% vs. $41.98 \%)$ was encountered in the patients group as compared with controls. The risk to develop sporadic CRC was found to be 3.05 (95\%CI, [1.86-5.05], $\mathrm{p}<0.001), 1.54$ (95\%CI, [0.96-2.49], $\mathrm{p}=0.06)$ and $2.6(95 \% \mathrm{CI},[1.61-4.24], \mathrm{p}<0.001)$, respec- tively in carriers of Arg399Gln-XRCC1, Lys751Gln-XPD and Thr241Met-XRCC3 genetic variations.

Based on the data obtained from the questionnaires, we analyzed the possible influence of Arg399Gln-XRCC1, Lys751Gln-XPD and Thr241Met-XRCC3 genotypes on the metabolization of carcinogens from tobacco smoke and diet in both women and men (Tables II, III, IV, $V$ ). Furthermore, we checked for the influence of genetic and environmental exposure on early-onset sporadic colorectal cancer in both females and males (Tables VI, VII).

\section{Discussion}

Colorectal cancer, a multifactorial and complex disease, represents one of the common cancers that occur worldwide. If, for inherited diseases, such as hereditary non-polyposis colorectal cancer, there are susceptibility genes, for sporadic colorectal cancer many genetic variants interact with each other and with environmental factors, increasing susceptibility to cancer. Genetic variations such as those affecting the two repair pathways, NER and BER, could represent susceptibility factors for sporadic colorectal cancer when interacting with environmental exposure (4,6-8).

We found a higher frequency of all these three polymorphisms in sporadic colorectal cancer patients as compared to controls. Our results were in agreement with those obtained by Abdel-Rahman et al (2000), Yeh et al (2005), Mort et al (2003), Stern et al (2009), Jelonek et al (2010) and Kabzińsk et al (2010) (16-21).

In this study, we investigated the role of environmental risk factors as modulating factors for sporadic colorectal cancer risk in the presence of different genetic variations in DNA repair genes in a Romanian population. While studies such as those performed by Stern et al (2005), Bigler et al (2005), Skjelbred et al (2006) Huang et al (2006) 
and Improta et al (2008) have investigated the role of DNA repair gene polymorphisms as risk factors for colorectal cancer, only few studies have investigated the interaction between these polymorphisms and environmental risk factors such as smoking behavior and alcohol intake (22-26). To the best of our knowledge, this is the first Romanian study that investigates the role of DNA repair gene variants as modulators of the effect of smoking or diet on colorectal cancer risk in both females and males. This is also the first study that investigates the role of genetic risk factors associated with environmental risk factors in the onset of sporadic colorectal cancer.

\section{Interaction between XRCC1-Arg399Gln and environmental risk factors}

Arg399Gln (G399A) involves the $G$ to $A$ transition in exon 10 (position 28152) of the XRCC1 gene. Although functional consequences are unknown, this genetic variation could alter protein interaction (15). The study performed by Yarosh et al (2005) showed that patients with the homozygous Gln399/Gln399 genotype are more resistant to anticancer drugs (27). Several other studies carried out in different populations have reported an association between the Gln399 allele in the XRCC1 gene and smoking as a risk factor for sporadic colorectal cancer. Stern et al. (2006) showed that among the Los Angeles population, the Arg399Gln-XRCC1 genetic variation is linked with colorectal adenomas in smoking patients (28).

We found a significantly higher risk for sporadic colorectal cancer in smoking men positive for at least one of the Gln399- XRCC1 allele. Even if the risk is also increased for females, results were not statistically significant. Our results are in agreement with those obtained by Stern et al (2006) but in contrast with the results obtained from other populations of the world (25). The studies of Taylor et al. (2002) and Takanam et al (2005) failed to find any association between smoking, the XRCC1 genetic variation and the risk for colorectal cancer $(29,30)$. Regarding the interaction of diet and the XRCC1 genetic variation, a significantly increased risk for sporadic colorectal cancer was observed in females who ate fried red meat more than five days a week. In contrast, in male individuals, a diet rich in fried red meat had a major influence on sporadic colorectal cancer risk in both positive and negative individuals, independently of the genotype.

\section{Interaction between XPD-Lys751Gln and environmental risk factors}

The Lys751Gln genetic variation represents a point substitution A to $\mathrm{C}$ in position 35931, exon 23 of the XPD gene, which determines the substitution of Lys with Gln in position 751 of the protein. Smoking could represent a risk factor for sporadic colorectal cancer in both females and males. However, a significantly higher risk was observed for smoking patients in association with XPD genetic variations. Thus, our study found that the presence of at least one Gln751 allele could influence the risk of sporadic colorectal cancer in both smoker females and males. The results were in accordance with those obtained by Bigler et al (2005), but not with those obtained by Huang et al (2006) and Stern et al (2006) $(22,23,25)$. We found a stronger association between a diet rich in fried red meat intake and colorectal cancer risk in both females and males, independently of the Gln751-XPD allele.

The explanation for our results could be that XPD with DNA helicase activity plays an important role in nucleotide excision repair, by inducing DNA helix opening, allowing the excision of damaged DNA (10). The Gln751 allele is associated with a lower DNA repair capacity of the DNA damage produced by carcinogens. Because smoking has a higher amount of carcinogens, it has been suggested that the activity of the XPD protein might modulate the DNA damaging effects of smoking (31). 


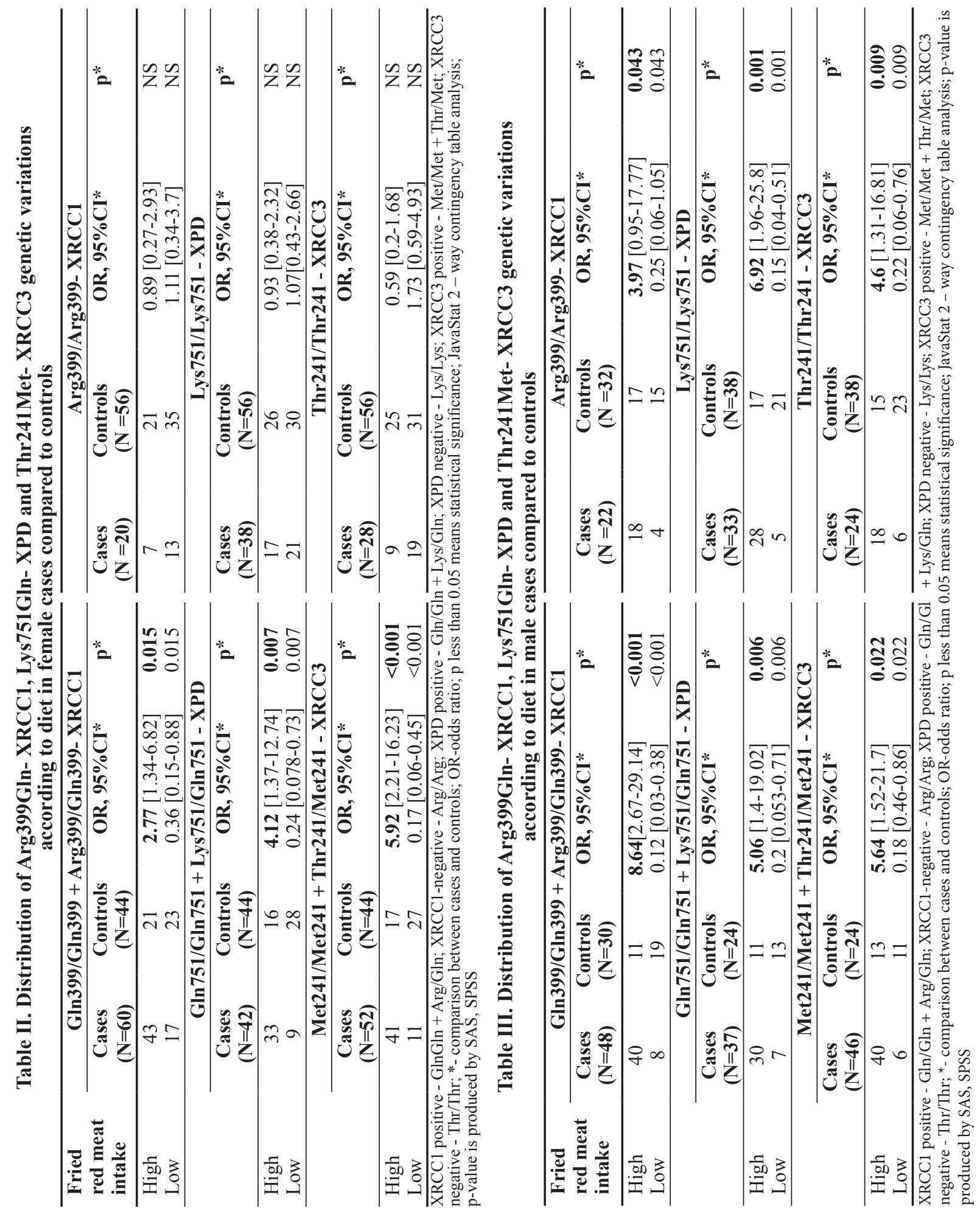




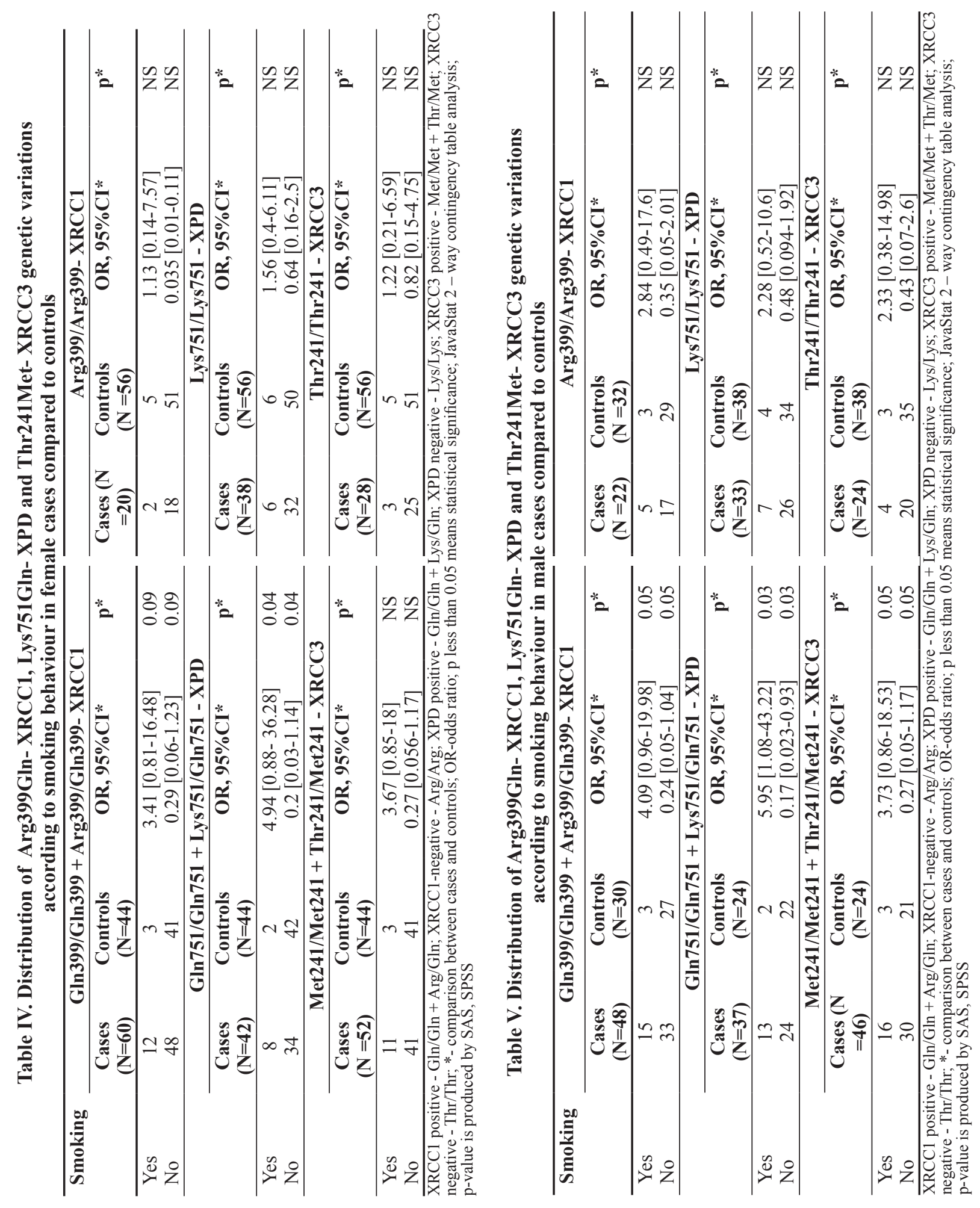




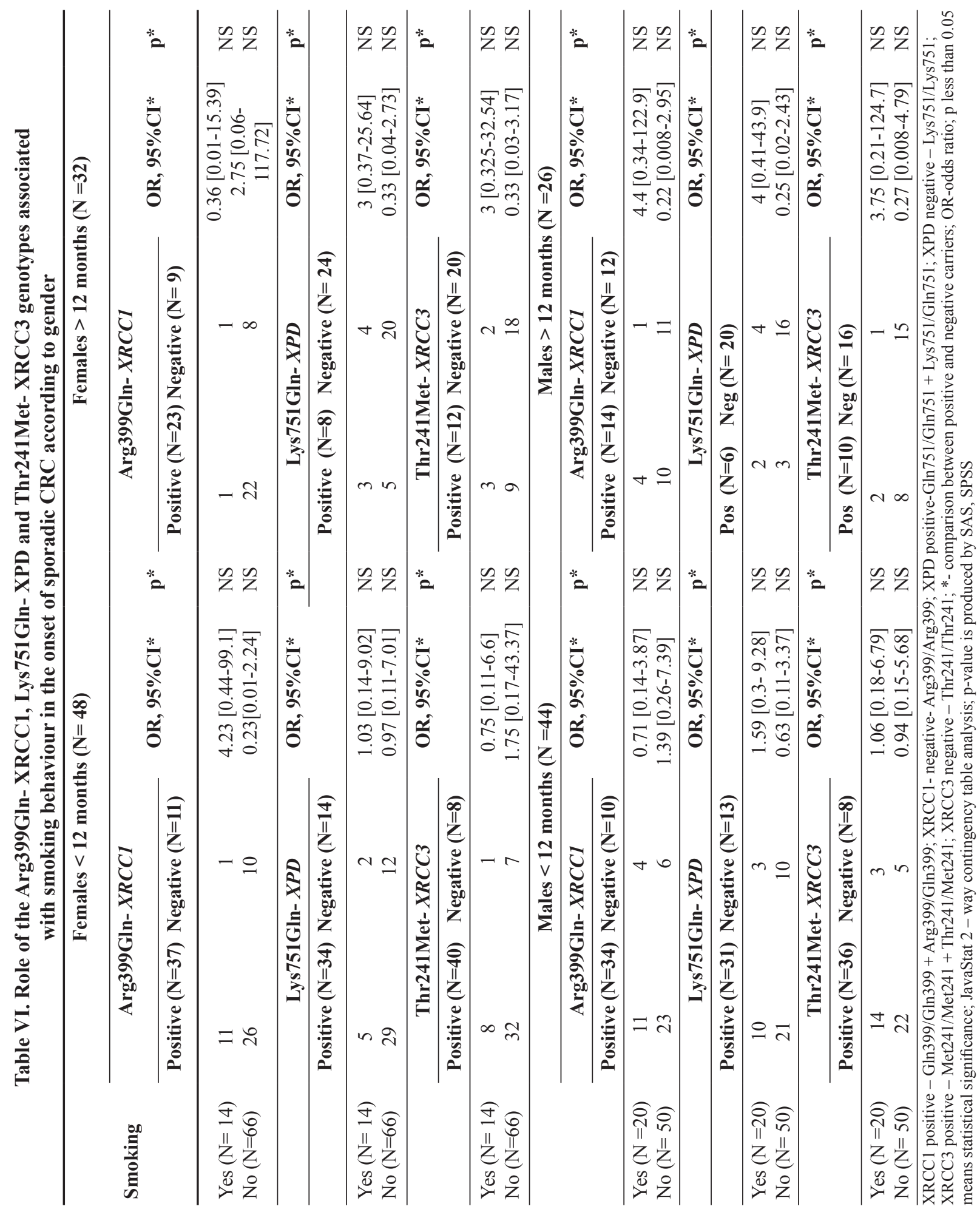




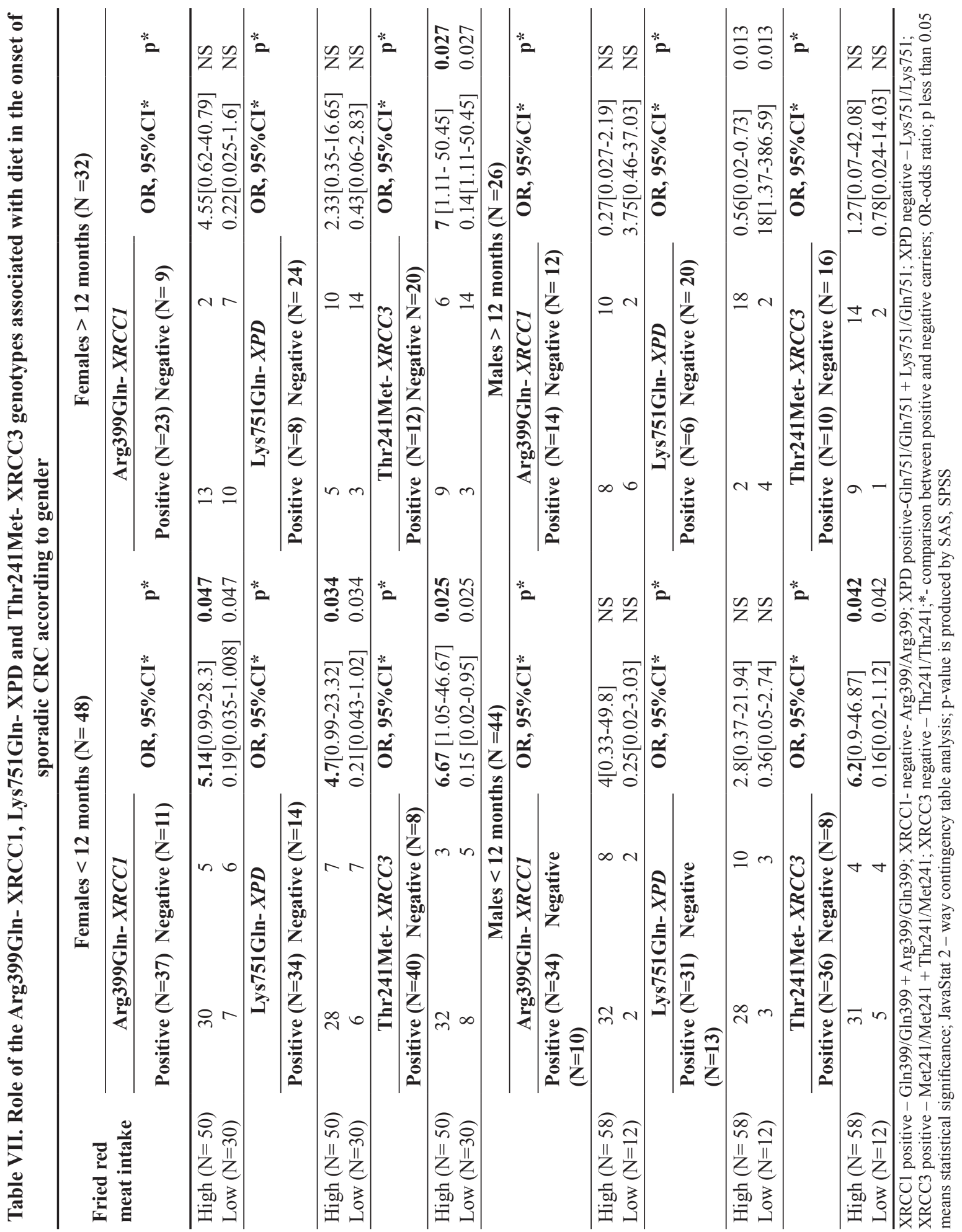




\section{Interaction between XRCC3-Thr241Met and environmental risk factors}

Some genetic variations in XRCC3 genes could affect chromosomal instability. One of these is the Thr241Met (T241M) which involves the substitution of $\mathrm{C}$ with $\mathrm{T}$ in exon 7 (position 18067 ) of the XRCC3 gene. It is possibly associated with impaired repair function because this substitution influences the enzyme's function by removing a phosphorylation site $(32,33)$.

Regarding the Thr241Met-XRCC3 genetic variation, our results showed that, while both smoker females and males had an increased risk for sporadic colorectal cancer in the presence of this polymorphism, a significant association was found in smoker males. In males, diet rich in fried red meat intake represents an independent risk factor for sporadic colorectal cancer. The risk is nonetheless higher in carriers of the Thr241Met -XRCC3 variation. In women negative for this polymorphism, diet does not represent a risk factor for sporadic colorectal cancer. However, the risk is significantly increased in females positive for this polymorphism, with a diet rich in fried red meat. The Thr241Met-XRCC3 genetic variation along with smoking behavior have been linked with sporadic colorectal cancer in several studies in different populations worldwide, but in other studies such as that performed by Tranah et al (2004) and Stern et al (2006), there was no association found $(22,34)$.

\section{Association between mutated XRCC1, $X R C C 3$ and XPD genotypes and lifestyle as a modulator for the onset of sporadic colorectal cancer}

Association between smoking and Arg399Gln- XRCC1 genetic variation is an increased risk factor for early-onset sporadic colorectal cancer in females. Also, association between smoking and Lys751Gln- XPD or Thr241MetXRCC3 genetic variations represents a risk factor for late-onset colorectal cancer in females.
In male patients, late-onset sporadic colorectal cancer was found in smokers positive for the three polymorphisms. Female patients who ate fried red meat more than 5 days a week had a significantly higher risk to develop early-onset sporadic colorectal cancer if they were carriers of Arg399Gln-XRCC1, Lys751Gln-XPD and Thr241Met-XRCC3 genetic variations. Also, they had a higher risk to develop late-onset sporadic colorectal cancer if they were negative for these polymorphisms, but the results were not statistically significant.

In male individuals, association between diet and Arg399Gln-XRCC1, Lys751Gln-XPD and Thr241Met-XRCC3 genetic variations does not represent a risk factor for late-onset sporadic colorectal cancer. But, male individuals positive for Arg399Gln-XRCC1, Lys751Gln-XPD and Thr241Met-XRCC3 genetic variations, with a diet rich in fried red meat intake, had a higher risk to develop early-onset sporadic colorectal cancer. The results were statistically significant only for the Thr241Met-XRCC3 carriers.

\section{Conclusions}

Our study confirms the influence of the genetic variations in DNA repair genes XRCC1, XPD and XRCC3 on the metabolization of carcinogens from tobacco smoke and diet. In Romanians, the association between the mutated genotypes and environmental risk factors modulates the risk for sporadic colorectal cancer. The results confirm the hypothesis that the mutated genotypes affect the repair of DNA lesions in individuals with such unhealthy behavior and genetic factors and environmental exposure act simultaneously in the carcinogenesis of sporadic colorectal cancer. Smoking in association with the Arg399Gln-XRCC1 genetic variation influences the early onset of sporadic colorectal cancer in females. Diet rich in fried red meat in- 
take associated with Arg399Gln-XRCC1, Lys751Thr-XPD and Thr241Met-XRCC3 genetic variations significantly influences the early onset of sporadic colorectal cancer in females.

\section{Conflict of interest: None declared.}

\section{References}

1. Reid ME, Marshall JR, Roe D, Lebowitz M, Alberts $\mathrm{D}$, Battacharyya AK, et al. Smoking exposure as a risk factor for prevalent and recurrent colorectal adenomas. Cancer Epidemiol Biomarkers Prev. 2003;12(10):100611.

2. Anderson JC, Attam R, Alpern Z, Messina CR, Hubbard P, Grimson R, et al. Prevalence of colorectal neoplasia in smokers. Am J Gastroenterol. 2003;98(12):2777-83. DOI: $10.1111 / \mathrm{j} .1572-0241.2003 .08671 . \mathrm{x}$

3. Jacobson JS, Neugut AI, Murray T, Garbowski GC, Forde KA, Treat MR, et al. Cigarette smoking and other behavioral risk factors for recurrence of colorectal adenomatous polyps. Cancer Causes Control. 1994;5(3):215-220. DOI: 10.1007/BF01830239

4. Ye YN, Wu WK, Shin VY, Cho CH. A mechanistic study of colon cancer growth promoted by cigarette smoke extract. Eur J Pharmacol. 2005;519(1-2):52-7. DOI: 10.1016/j.ejphar.2005.07.009

5. Ye YN, Wu WK, Shin VY, Bruce IC, Wong BC, Cho $\mathrm{CH}$. Dual inhibition of 5-LOX and COX-2 suppresses colon cancer formation promoted by cigarette smoke. Carcinogenesis. 2005;26(4):827-34. DOI: 10.1093/car$\mathrm{cin} /$ bgi012

6. Kotzev I, Mirchev M, Manevska B, Ivanova I, Kaneva M. Risk and protective factors for development of colorectal polyps and cancer (Bulgarian experience). Hepatogastroenterology. 2008;55(82-83):381-7.

7. Lampe JW. Diet, genetic polymorphisms, detoxification and health risks. Altern Ther Health Med. 2007;13(2):S108-11.

8. Sørensen M, Autrup H, Olsen A, Tjønneland A, Overvad K, Raaschou-Nielsen O. Prospective study of NAT1 and NAT2 polymorphisms, tobacco smoking and meat consumption and risk of colorectal cancer. Cancer Lett. 2008;266 (2):186-193. DOI: 10.1016/j. canlet.2008.02.046

9. Brooks PJ, Theruvathu JA. DNA adducts from acetaldehyde:implications for alcohol-related carcinogenesis. Alcohol 2005;35(3):187-193. DOI: 10.1016/j.alcohol.2005.03.009

10. Lechman AR. The xeroderma pigmentosum group $\mathrm{D}$ (XPD) gene:one gene, two functions, three diseases. Genes Dev. 2001;15(1):15-23. DOI: 10.1101/ $\operatorname{gad} .859501$

11. Matullo G, Palli D, Peluso M, Guarrera S, Carturan S,
Celentano E, et al. XRCC1, XRCC3, XPD gene polymorphisms, smoking and 32P-DNA adducts in a sample of healthy subjects. Carcinogenesis. 2001;22(9):143745. DOI: $10.1093 /$ carcin/22.9.1437

12. Sung P, Bailly V, Weber C, Thompson LH, Prakash L, Prakash S. Human xeroderma pigmentosum group D gene encodes a DNA helicase. Nature. 1993;365(6449):852-5. DOI: 10.1038/365852a0

13. Cui X, Brenneman M, Meyne J, Oshimura M, Goodwin $\mathrm{EH}, \mathrm{Chen} \mathrm{DJ}$. The XRCC2 and XRCC3 repair genes are required for chromosome stability in mammalian cells. Mutat Res. 1999;434(2):75-88. DOI: 10.1016/S09218777(99)00010-5

14. Lunn RM, Helzlsouer KJ, Parshad R, Umbach DM, Harris EL, Sanford KK, et al. XPD polymorphisms:effects on DNA repair profiency. Carcinogenesis. 2000;21(4):551-5. DOI: 10.1093/carcin/21.4.551

15. Lunn RM, Langlois RG, Hsieh LL, Thompson CL, Bell DA. XRCC1 polymorphisms:effects on aflatoxid B1-DNA adducts and glycophorin A variant frequency. Cancer Res. 1999;59(11):2557-61.

16. Abdel-Rahman SZ, Soliman AS, Bondy ML, Omar S, El-Badawy SA, Khaled HM, et al. Inheritance of the 194Trp and the 399Gln variant alleles of the DNA repair gene XRCC1 are associated with increased risk of early-onset colorectal carcinoma in Egypt. Cancer Lett. 2000;159(1):79-86. DOI: 10.1016/S03043835(00)00537-1

17. Yeh CC, Sung FC, Tang R, Chang-Chieh CR, Hsieh LL. Polymorphisms of the XRCC1, XRCC 3 and XPD genes and colorectal cancer risk:a case-control study in Taiwan. BMC Cancer. 2005;5:12-17. DOI: 10.1186/14712407-5-12

18. Mort R, McEwan C, Melton DW. Lack of involvement of nucleotide excision repair gene polymorphisms in colorectal cancer. Br J Cancer. 2003;89(2):333-7. DOI: 10.1038/sj.bjc. 6601061

19. Stern MC, Butler LM, Corral R, Joshi AD, Yuan JM, Koh WP, et al. Polyunsaturated fatty acids, DNA repair nucleotide polymorphisms and colorectal cancer in the Singapore Chindws health study. J Nutrigenet Nutrigenomics. 2009;2(6):273-9. DOI: 10.1159/000308467

20. Jelonek K, Gdowicz-Klosok A, Pietrowska M, Borkowska M, Korfanty J, Rzeszowska-Wolny J, et al. Association between single nucleotide polymorphisms of selected genes involved in the response to DNA damage and risk of colon, head and neck, and breast cancers in a Polish population. J Appl Genet. 2010;51(3):343-52. DOI: $10.1007 / \mathrm{BF} 03208865$

21. Kabzińsk J, Przybyłowsk K, Mik M, Sygut A, Dziki L, Dziki A. An association of Arg399Gln polymorphism of XRCC1 gene with a risk of colorectal cancer. Polski Przegląd Chirurgiczny. 2010;82 (12):677-80. DOI: 10.2478/v10035-010-0103-0

22. Stern MC, Siegmund KD, Corral R, Haile RW. 
XRCC1 and XRCC3 polymorphisms and their role as effect modifiers of unsaturated fatty acids and antioxidant intake on colorectal adenomas risk. Cancer Epidemiol Biomarkers Prev. 2005;14(3):609-15. DOI: 10.1158/1055-9965.EPI-04-0189

23. Bigler J, Ulrich CM, Kawashima T, Whitton J, Potter JD. DNA repair polymorphisms and risk of colorectal adenomatous or hyperplastic polyps. Cancer Epidemiol Biomarkers Prev. 2005;14 (11):2501-8. DOI: 10.1158/1055-9965.EPI-05-0270

24. Skjelbred CF, Saebo M, Wallin H. Polymorphisms of the XRCC1, XRCC3 and XPD genes and risk of colorectal adenoma and carcinoma, in a Norwegian cohort:a case control study. BMC Cancer. 2006;6(1):67. DOI: $10.1186 / 1471-2407-6-175$ DOI: $10.1186 / 1471-$ 2407-6-67

25. Huang W-Y, Berndt SI, Kang D, Chatterjee N, Chanock SJ, Yeager M, et al. Nucleotide excision repair gene polymorphisms and risk of advanced colorectal adenoma: XPC polymorphisms modify smoking-related risk. Cancer Epidemiol Biomarkers Prev. 2006;15(2):30611. DOI: 10.1158/1055-9965.EPI-05-0751

26. Improta G, Sgambato A, Bianchino G, Zupa A, Grieco $\mathrm{V}$, La Torre G, et al. Polymorphisms of the DNA repair genes XRCC1 and XRCC3 and risk of lung and colorectal cancer: a case-control study in a Southern Italian population. Anticancer Res. 2008;28(5B):2941-6.

27. Yarosh DB, Pena A, Brown DA. DNA repair gene polymorphisms affect cytotoxicity in the National Cancer Institute Human Tumour Cell Line Screening Panel. Biomarkers. 2005;10(2-3):188-202. DOI: $10.1080 / 13547500500138732$
28. Stern MC, Siegmund KD, Conti DV, Corral R, Haile RW. XRCC1, XRCC3, and XPD Polymorphisms as Modifiers of the Effect of Smoking and Alcohol on Colorectal Adenoma Risk. Cancer Epidemiol Biomarkers Prev. 2006;15(12):2384-90. DOI: 10.1158/10559965.EPI-06-0381

29. Taylor RM, Thistlethwaite A, Caldecott KW. Central role for the XRCC1 BRCT I domain in mammalian DNA single-strand break repair. Mol Cell Biol. 2002;22(8):2556-63. DOI: 10.1128/MCB.22.8.25562563.2002

30. Takanami T, Nakamura J, Kubota Y, Horiuchi S. The Arg280His polymorphism in X-ray repair cross-complementingg ene 1 impairs DNA repair ability. Mutat Res. 2005;582:135-45. DOI: 10.1016/j.mrgentox.2005.01.007

31. Benhamou S, Sarasin A. ERCC2 /XPD gene polymorphisms and lung cancer:a HuGE review. Am J Epidemiol. 2005;161(1):1-14. DOI: 10.1093/aje/kwi018

32. Savas S, Ozcelik H. Phosphorylation states of cell cycle and DNA repair proteins can be altered by the NsSNPs. BMC Cancer. 2005;5:107. DOI: 10.1186/1471-2407-5107

33. Ladiges W, Wiley J, MacAuley A. Polymorphisms in the DNA repair gene XRCC1 and age-related disease. Mech Ageing Dev. 2003;124(1):27-32. DOI: 10.1016/ S0047-6374(02)00166-5

34. Tranah GJ, Giovannucci E, Ma J, Fuchs C, Hankinson SE, Hunter DJ. XRCC2 and XRCC3 polymorphisms are not associated with risk of colorectal adenoma. Cancer Epidemiol Biomarkers Prev. 2004;13(6):1090-1. 